\title{
Recovery of microalgal biomass and metabolites from homogenized, swirl flash-dried microalgae
}

\author{
Ljubic, Anita; Safafar, Hamed; Jacobsen, Charlotte
}

Published in:

Journal of Applied Phycology

Link to article, DOI:

$10.1007 / \mathrm{s} 10811-019-1733-1$

Publication date:

2019

Document Version

Peer reviewed version

Link back to DTU Orbit

Citation (APA):

Ljubic, A., Safafar, H., \& Jacobsen, C. (2019). Recovery of microalgal biomass and metabolites from homogenized, swirl flash-dried microalgae. Journal of Applied Phycology, 31(4), 2355-2363.

https://doi.org/10.1007/s10811-019-1733-1

\section{General rights}

Copyright and moral rights for the publications made accessible in the public portal are retained by the authors and/or other copyright owners and it is a condition of accessing publications that users recognise and abide by the legal requirements associated with these rights.

- Users may download and print one copy of any publication from the public portal for the purpose of private study or research.

- You may not further distribute the material or use it for any profit-making activity or commercial gain

- You may freely distribute the URL identifying the publication in the public portal

If you believe that this document breaches copyright please contact us providing details, and we will remove access to the work immediately and investigate your claim. 


\section{Recovery of microalgal biomass and metabolites from homogenised, swirl flash}

\section{2 dried microalgae}

3 Anita Ljubic ${ }^{1 *}$, Hamed Safafar $^{2}$ and Charlotte Jacobsen ${ }^{1}$

$4 \quad{ }^{1}$ Technical University of Denmark, National Food Institute, Kemitorvet, Building 202, Kongens Lyngby 2800, Denmark;

5 chja@food.dtu.dk $(0000-0003-3540-9669)$

$6 \quad{ }^{2}$ BioMar A/S, Mylius-Erichsensvej 35, 7330 Brande, Denmark; hamsa@biomar.dk (0000-0002-8538-7456)

7 *Author for correspondence:e-mail: aniljub@food.dtu.dk (0000-0001-9370-8830), phone:+458161 1094

9 Abstract: Production of intracellular metabolites from microalgae involves various processing steps. Since algal drying and cell disruption are integral processes of the these operations, effects of novel swirl flash drying technique and cell cracking by high pressure liquid shear method were tested. Variations in biomass composition (focusing on the fatty acid and pigment composition) of two microalgal species, Chlorella pyrenoidosa and Nannochloropsis salina, were studied in order to investigate effects of novel drying technique, including whether recovery of bioactive compounds is more efficient on dried or wet biomass. Applying novel swirl flash drying technique showed no significant adverse effect on the fatty acid composition, including heat sensitive eicosapentaenoic acid (EPA), of tested microalgal species. Pigment and tocopherol composition of $C$. pyrenoidosa showed tendency to degrade after applying both cell cracking and drying treatment. Considering these data swirl flash drying technique has a potential as a new drying technique for microalgae biomass. 


\section{Introduction}

28 Growing interest in natural and healthy foods and food ingredients is forcing development of novel products with functional ingredients. Microalgae have been recognized as a potential source for various valuable ingredients with positive health effects for commercial applications. These microorganisms are able to produce polyunsaturated fatty acids, pigments, vitamins, peptides and many other bioactive compounds. Production of intracellular metabolites from microalgae involves upstream and downstream processing steps. Upstream processing includes cultivation during which microalgal biomass is being produced, while downstream processing includes harvesting and recovery of the metabolites. After cultivation biomass needs to be harvested, up-concentrated and dried before further processing. Dewatered algae slurry is being dried in order to facilitate transportation, decrease the risk of unwanted deterioration and to extend the shelf life. However, drying of microalgae biomass is still very challenging and requires an innovative answer. Mostly because drying exerts a major economic constraint in the process and it may constitute up to $75 \%$ of the overall cost (Shelef et al. 1984; Show et al. 2013). Common drying methods include either natural traditional method as solar drying or using more advanced techniques such as freeze drying, spray drying, drum drying or fluidized bed drying (Show et al., 2015). Solar drying is cost effective compared to other techniques, but is also a relatively slow and unreliable method, which can result in altered nutritional value and safety of the final product. On the other hand, controlled freeze drying keeps the product temperature low enough during the process to avoid changes in the dried product appearance and characteristics. It is a gentle process in and commonly the best choice in order to preserve the quality of the biomass. However, the predominant deficiency of freeze drying is the high operating cost (Grima et al. 2003). Furthermore, if the biomass is not undergoing a heat treatment before freeze drying, the presence of lipolytic enzymes such as lipase will hydrolyse lipids and lead to formation of high levels of free fatty acids, which is undesirable. Spray drying is the most commonly used technique in commercial production, but despite the fact that it is a very efficient drying method, it may cause unwanted cell rupture and result in microalgae biomass degradation (Show et al. 2015). Shortcoming of spray drying may be its highpressure atomization process, unless atomization is carried out without the use of nozzles which are susceptible to blockage, high capital and energy demands as well as thermal decomposition of bioactive compounds (Orset et al., 1991; Lin 1985) 
56 The main consideration in the selection of the drying technology depends on the production scale and

57 the final purpose for which the microalgae biomass is intended. Important factors to consider are also 58 moisture content, quality requirements and maximum acceptable temperature for preventing thermal 59 damage to the biomass. In this study, a prototype novel swirl flash dryer system, which was designed 60 and constructed in one of our previous projects (Safafar 2017), was used for drying trials. In general, 61 flash drying is achieved by rapid removal of moisture by injecting wet microalgae slurry into a hot air 62 stream, which serves as a carrier for mass transfer of moisture from microalgae slurry to the gases 63 (Debrand 1974). In the novel process design, liquid phase is being removed very fast, which requires 64 less heat as a driving force so that the bioactive cell constituents are preserved. Swirl flash drying in 65 theory is a combination of fluidized and flash drying and this technology has never been used for the 66 drying of microalgae. In swirl flash dryer system, microalgae biomass is introduced to the drying 67 chamber, which is distributed by the scraping paddles (which are moving close to the drying chamber walls) and fluidized in the stream of the spirally-flow stream of hot air. The energy consumption per unit of the drying by swirl flash dryer was estimated to be $28 \%$ less than spray drying for the same product (Safafar 2017). It uses less energy per kg of dry biomass, requires less investment and less area for the drying unit comparing to spray drying under the same condition (Katie 2000; Pertick et al. 2013). Furthermore, this system could be operated in small scale (10-100 kg of the slurry), which may be desired for the microalgae cultivation systems.

74 Understanding the possible effects of drying methods on microalgae biomass quality is very important to improve the efficiency of algal high value ingredients production. Therefore, in this study effects of two different drying methods (novel swirl flash drying and freeze drying) on the biomass composition of two microalgal specie, Chlorella pyrenoidosa (also known as Auxenochlorella pyrenoidosa) and Nannocloropsis salina (also known as Microchloropsis salina), were compared (focusing on the fatty acid and pigment composition), including whether recovery of bioactive compounds is more efficient on dried or wet biomass. In order to enhance extraction of bioactive compounds, microalgae cell walls often needs to be cracked. Since high pressure liquid shear methods such as homogenization have proven to be successful on microalgae cell disruption (Spiden et al. 2013), this technology has been used in order to evaluate whether recovery of metabolites from dry microalgae biomass was more efficient with or without this pre-treatment. During this mechanical process, liquid dispersion of a cell 
biosuspension is forced by high pressure through a micrometric disruption chamber. As a result, cell suspension is exposed to intense fluid-mechanical stresses, including shear, turbulence, elongation, and cavitation that may cause the physical disruption of the cell wall and other cell constituents (Chisti and Moo-Young, 1986).

\section{Materials and methods}

\subsection{Microalgae biomass}

Two microalgae, Chlorella pyrenoidosa (SAG 211-8k) and Nannochloropsis salina (SAG 40.85) were selected for drying trials and to evaluate its effect on the biochemical composition. C. pyrenoidosa was cultivated in industrial scale in Ecoduna (Bruck an der Leitha, Austria) and N. salina was cultivated in microalgal pilot plant facilities in Kalundborg (Denmark) (Safafar et al., 2016). Harvesting was done at early stationary phase by cross-flow microfiltration from LiqTech ( $\mathrm{SiC}$ ceramic membrane, $0.1 \mu \mathrm{m}$ ) and the biomass was up concentrated by centrifugation (6500 $x \mathrm{~g}$ for $\mathrm{N}$. salina and $3000 \times \mathrm{g}$ for $C$. pyrenoidosa) prior to shipment to Technical University of Denmark (DTU). Final dry matter (DM) of C. pyrenoidosa and N. salina after centrifugation was $12.5 \pm 0.1 \%$ and $17.0 \pm 2.0 \%(\mathrm{w} / \mathrm{w})$, respectively.

\subsection{Biomass pretreatment - cell rupture}

High-pressure homogenization (Rannie 110, SPX Flow Technology, Søborg, Denmark) was applied to the microalgae samples of $C$. pyrenoidosa in order to investigate the effect of cell rupture on the recovery of microalgal biomass and metabolites. Positive displacement piston pump was used to accelerate the slurry flow through an orifice within an assembly of specially designed valves creating high shear forces, which result in cell wall destruction. Around $1.5 \mathrm{~L}$ of cooled $\left(\approx+5 \mathrm{C}^{\circ}\right)$ microalgal slurry of $C$. pyrenoidosa (dry solid content $12.5 \% \mathrm{w} / \mathrm{w}$ ) passed the nozzles at a pressure of $150 \mathrm{M} \mathrm{Pa}$ and flow rate of $250 \mathrm{ml} / \mathrm{min}$. The same sample was running two times through the homogenizer since our preliminary experiments showed that there was almost no cell rupture detected after the first run. After homogenization the degree of cell rupture was evaluated visually by optical microscopy and then the samples were stored at $-20^{\circ} \mathrm{C}$. 


\subsection{Drying experiments}

113 Microalgal biomass samples of $N$. salina and $C$. pyrenoidosa were dried by freeze drying in a pilot 114 scale freeze dryer (Beta 1-8, Martin Christ GmbH, Osterode, Germany) and by swirl flash drying prototype (Fig. 1). Freeze drying was carried out by placing the frozen samples (at $-20{ }^{\circ} \mathrm{C}$ ) under a vacuum where heat energy is then added to the product causing the ice to sublime. The drying conditions for the swirl flash drying are shown in Table 1. Dry biomass was stored at $-20{ }^{\circ} \mathrm{C}$ prior to chemical analysis.

\section{2.4. Analytical analysis}

120 Protein content

121 The protein content in the samples was estimated based on total nitrogen content, which was 122 determined using the Dumas method (Elementar, Mt. Laurel, NJ, USA) for the quantitative measurements of protein in different substances. Approximately $1 \mathrm{~g}$ of the dried microalgal biomass was used for analyses. The following steps were automated including sample combustion in a chamber at a high temperature $\left(900{ }^{\circ} \mathrm{C}\right)$ in the presence of oxygen. Estimation of the total protein content was done using total nitrogen determination and conversion factor 4.44 (Lopez at al. 2010). Conversion factor value of 4.44 is recommended to be used to estimate the protein content if total nitrogen is measured. It was determined based on testing several microalgae and cyanobacteria undergoing rapid growth. Protein content is reported as \% of dry biomass. Analyses were carried out in duplicate.

\section{Total lipid content}

Lipid extraction was done as described by Bligh \& Dyer (1959), but with a reduced amount of solvent (30 $\mathrm{mL}$ of each). Approximately $1 \mathrm{~g}$ of the dried microalgal biomass was weighted and placed into extraction glass. Before extraction samples were sonicated in sonication bath (Buch \& Holm A/S, Herlev, Denmark) for $10 \mathrm{~min}$ at $10-15{ }^{\circ} \mathrm{C}$ in order to enhance cell rupture. Extraction was carried out by subsequent addition of methanol, chloroform and water while stirring. In order to separate methanol/water phase from chloroform/oil phase, samples were centrifuged at $1400 \mathrm{x} g$ for $10 \mathrm{~min}$. Bligh \& Dyer extracts were used for analyses of oil content, fatty acids and tocopherols. Determination of total lipid content was done by weighing $15 \mathrm{~g}$ of extract in beakers and keeping it overnight in a fume hood in order to evaporate chloroform. Lipid content was calculated using the equation below (1). 
Fatty acids

144 Fatty acid profile was determined based on the American Oil Chemist's Society (AOCS) official 145 method Ce 1i-07 (Firestone 2009) with some modifications. Approximately 5 g of Bligh \& Dyer 146 extract was weighed in methylation glass tube and evaporated under the stream of nitrogen until 147 dryness. A mixture containing $100 \mu \mathrm{L}$ of internal standard solution (C23:0), $200 \mu \mathrm{L}$ of heptane with 148 butylated hydroxytoluene (BHT) and $100 \mu \mathrm{L}$ of toluene was added to the dry extract. Samples were 149 methylated in a microwave oven (Microwave 3000 SOLV, Anton Paar, Ashland, VA, USA) for 10 min 150 at $100{ }^{\circ} \mathrm{C}$ and power of 500 watts. After methylation, heptane with BHT $(0.7 \mathrm{~mL})$ and saturated salt 151 water $(1 \mathrm{~mL})$ were added. The upper phase (heptane) was transferred into GC vials and analyzed by gas 152 chromatography equipped with flame ionization detector (GC-FID). (HP-5890 A, Agilent 153 Technologies, Santa Clara, CA, USA). Fatty acid methyl esters were separated by the GC column Agilent DB wax 127-7012 (10 $\mu \mathrm{m}$ x $100 \mu \mathrm{m}$ x $0.1 \mu \mathrm{m})$ (Agilent technologies, Santa Clara, CA, USA). Standard mix of fatty acids methyl esters (Sigma, St. Louis, MO, USA) was used for fatty acid identification. Fatty acids were quantified as area $\%$ of total fatty acids. Analyses were carried out in duplicate.

\section{Tocopherols}

160

Approximately $1 \mathrm{~g}$ of Bligh \& Dyer extract was weighed in glass tube and evaporated to dryness in darkness and under a stream of nitrogen. Dry extract was re-dissolved in a mixture of isopropanol: heptane $(0.5: 99.5, \mathrm{v} / \mathrm{v})$. The solution was filtered by $0.22 \mu \mathrm{m}$ PTFE syringe filter and $20 \mu \mathrm{L}$ of filtrate was injected to HPLC. Analysis was done based on the AOCS official method as (Firestone, 2009) using an Agilent 1100 Liquid Chromatograph equipped with a fluorescence detector, with the excitation wavelength set at $290 \mathrm{~nm}$ and emission wavelength at 330. The separation was carried out in isocratic mode by Spherisorb column (150 $\mathrm{mm}$ x $46 \mathrm{~mm}$ with $3 \mu \mathrm{m}$ particle size) at room temperature using a mixture of isopropanol: $\mathrm{n}$ - heptane $(0.5: 99.5, \mathrm{v} / \mathrm{v})$ as mobile phase. Elution flow rate was $1 \mathrm{ml}$ $\min ^{-1}$. Analyses were carried out in duplicate. 
Pigments

171 Pigment analysis was done according to the method described by Safafar et al. (2015). Approximately

$1720.05 \mathrm{~g}$ of the dried algal biomass was weighted in centrifugation tubes. Extraction was carried out by 173 methanol containing BHT in a sonication bath (Buch \& Holm A/S, Herlev, Denmark) for 15 min at $1745 \pm 2{ }^{\circ} \mathrm{C}$. Pigment analysis was performed by HPLC using Agilent 1100 Liquid Chromatograph with 175 diode array detector (DAD). Separation was carried out on a Zorbax Eclipse C8 column $150 \mathrm{~mm}$ x 46 $176 \mathrm{~mm} \times 3.5 \mu \mathrm{m}$ (Phenomenex Inc. CA, USA) at $60^{\circ} \mathrm{C}$. The mobile phase was a mixture of $70 \%$ methanol $177+30 \%$ of $0.028 \mathrm{M}$ tertiary butyl ammonium acetate in water and methanol at a flow rate of $1.1 \mathrm{~mL}$ $178 \mathrm{~min}^{-1}$ with total acquisition time of $40 \mathrm{~min}$. DHI pigment standard mix (DHI LAB Products, Horsholm, 179 Denmark) was used for identification of peaks. Detection of chlorophylls and carotenoids was done at $180660 \mathrm{~nm}$ and $440 \mathrm{~nm}$, respectively, and for internal standard (BHT) at $280 \mathrm{~nm}$. Pigments are reported as $\mu \mathrm{g} \mathrm{g}^{-1}$ dry biomass. Analyses were carried out in duplicate.

182

\subsection{Statistical analysis}

All compositional analyses were performed in two replicates. The results are given as the mean $( \pm$ standard deviation). Analysis of variance (two-way ANOVA) was used to evaluate the effect of homogenization and drying technique on chemical composition of biomass. Data have met the assumption of normality and homogeneity of variance. Tukey's post hoc test was used to detect significant differences between groups where $\mathrm{p}$ values $<0.01$ were considered significant. The Statistica v. 13.2 software (USA) was used for all statistical analyses.

\section{Results}

\section{Effect of drying and high-pressure homogenization}

The effect of homogenization on the cell rupture of $C$. pyrenoidosa is shown in Picture 1. Detectable cell rupture can be seen within the $C$. pyrenoidosa cells after homogenization. Optical micrographs are indicating that there is a mixture of material associated with cellular fragments and extracellular polymeric substances (EPS) (Picture 1b), extracted by the cell under stress conditions (Rossi et al. 2008). Results showed significantly higher lipid yield in dried and homogenized samples compared to non-dried and non-homogenized biomass (Table 2). On the other hand, protein content did not show any significant deviations between tested samples. The protein determination method that we used is 
200 based on the complete combustion at a high temperature $\left(900{ }^{\circ} \mathrm{C}\right)$ (section 2.4$)$ so there is no extraction 201 step included that may be affected by differently treated biomass. Effect of drying by swirl flash dryer 202 on the fatty acid composition of $N$. salina is shown in Table 3. Results are showing that there was no 203 significant adverse effect on the heat-sensitive polyunsaturated fatty acids, including EPA. The fatty 204 acid profile of $C$. pyrenoidosa also showed no significant difference among applied treatments (Table 205 4). Evaluation of the pigment composition of $N$. salina confirmed that there was no significant adverse 206 effect due to the drying process (Fig. 2). There was no significant degradation in concentration of heat207 sensitive carotenoids in the swirl flash dried biomass compared to the intact, non-dried biomass. 208 Slightly lower concentration of violaxanthin was detected in the dried samples (3217 \pm 248 compared 209 to $3882 \pm 21 \mu \mathrm{g} \mathrm{g}^{-1} \mathrm{DW}$ ), which may be the result of the heat-induced degradation. Ryckebosch et al. 210 (2011) found that freeze dried microalgae were more susceptible to lipolysis than spray-dried 211 microalgae, thus spray dried microalgae were more sensitive to pigment oxidation than freeze dried 212 microalgae, possibly due to breakdown of protecting carotenoids upon spray drying. Leach et al. (1998) 213 reported that spray drying affected $\beta$-carotene recoveries from D. salina, varying between $57 \%$ and $21491 \%$, depending on the drying temperature. Chlorophylls can convert at high temperature to the 215 undesirable degraded products (pheophytins) which function as a photoperoxidant resulting in 216 reduction of the storage time of the dried microalgae (Hosikian et al. 2010). Concentrations of 217 pheophytin and other chlorophyll degradation products were negligible in the present study, which 218 demonstrate that the drying treatment did not alter the chlorophylls structure. Compared to N. salina, 219 both freeze and flash drying had an adverse effect on pigment composition of C. pyrenoidosa (Fig. 3). 220 The highest concentration of total pigments was in non-dried, non-homogenized biomass (Table 5). 221 Chlorophylls showed significantly higher recovery in the intact biomass (non-dried, non-homogenized) 222 compared to dried and homogenized samples, which may indicate that both drying and high pressure 223 liquid shear methods reduce chlorophyll content in C. pyrenoidosa, specifically when both treatments 224 are subsequently applied. On the other hand, recovery of total carotenoids showed no significant 225 difference between dried and non-dried biomass. Carotenoids are thermo-sensitive and may decompose 226 during the drying process, or any other heating process (Takaichi 2011). However, the concentration of 227 carotenoids was found to be significantly lower in the non-dried biomass, which suggests that drying 228 (both freeze drying and swirl flash drying) may enhance carotenoids extractability. Also, there was no 229 significant reduction in carotenoid content after applying tested drying methods, for both homogenized 
230 and non-homogenized samples. Since chlorophylls are not heat-sensitive as carotenoids, oxidation 231 seems to be the reason of low chlorophyll recovery after drying, which is in agreement with 232 Stramarkou et al. (2017) study.

233 Tocopherol content in freeze and swirl flash dried biomass is presented in Fig. 4. Tocopherol is a lipid234 soluble antioxidant that is light and temperature sensitive (Carballo-Cardenas et al. 2003). Results 235 showed that there was significantly higher tocopherol content in dried, non-homogenized biomass 236 compared to dried-homogenized biomass (both swirl flash and freeze drying), which indicates that 237 cracking the cells before drying may affect degradation of tocopherols. However, swirl flash dried 238 biomass that was not exposed to the homogenization treatment prior to drying showed no significant 239 difference in tocopherol content compared to the freeze dried biomass. Tocopherol content had similar 240 trend as chlorophyll content in tested microalgal biomass, which confirms earlier given explanations.

\section{Discussion}

243 Homogenizers are using pumps to accelerate the liquid flow to a high velocity creating high shear 244 forces, which can destroy cell walls. Cell disruption is desirable in order to enhance recovery of 245 intracellular metabolites. Mendes-Pinto et al. (2001) reported that three times more astaxanthin from 246 Haematococcus was obtained after applying high-pressure homogenization, to disrupt its thick and 247 resistant cell wall, compared to the intact biomass. Intense fluid-mechanical stresses such as shear, 248 elongation, turbulence, and cavitation may cause the physical disruption of the cell wall and 249 membranes, as well as the macromolecules such as proteins. However, if high temperature is being 250 used in dehydration process it can enhance deterioration of these released value-added bioactive 251 compounds.

252

\section{$253 \quad$ Fatty acids}

254 It has been reported that drying process causes some structural changes in the cells and enables the 255 cellular components such as neutral lipids to be easily extracted (Show et al. 2015, Taher et al. 2014, Ryckebosch 2013). Unchanged cell structure of non-dried biomass holds a resistance to solvent 257 diffusion through the cell membrane, which may lead to low extraction efficiencies of lipids (Table 2). 258 However, some previous studies reported identical lipid levels from a given sample both after drying 259 and without any drying (Chatsungnoen and Chisti, 2016). One of the explanations for the contradicting 
260 findings could be that existing studies have tested different microalgae species and applied slightly 261 different extraction methods (repeated solvent extractions, different DM concentration in the wet 262 sample, different centrifugal forces used for up concentrating...). Our results indicate that the drying 263 step enhances lipid extractability in Chlorella pyrenoidosa but it doesn't necessarily exclude other 264 factors that may interact during the extraction procedure and which could have affected the results.

265 Algal drying and cell disruption are high-cost integral processes when it comes to bioactive compounds 266 recovery. As an example, for a product such as eicosapentaenoic acid (EPA, 20:5(n-3)), which is a 267 nutraceutical having therapeutic benefits in disease management, 60\% of the costs arise from the 268 recovery processes (Grima et al. 2003). Results of this study showed no significant change in fatty acid 269 composition of tested microalgae (Table 3,4). One of the justifications is a relatively rapid drying 270 process that enables short retention of the biomass at high temperatures $(3.3$ seconds drying time for $N$. 271 salina slurry with $17.0 \pm 2.0 \%$ of dry matter) that contributes to the bioactive content preservation. For 272 comparison, non-continuous drying process of the thick slurry from Scenedesmus sp. took $72 \mathrm{~h}$ by sun 273 drying, $12 \mathrm{~h}$ by oven drying at $60^{\circ} \mathrm{C}$ and $24 \mathrm{~h}$ by freeze drying (Guldhe et al. 2014). In microalgae, 274 membrane lipids commonly include polyunsaturated fatty acids (PUFAs), such as EPA and DHA 275 (docosahexaenoic acid). Since the results are showing that there was no significant difference in 276 relative composition of the EPA and other fatty acids of $N$. salina, it can be concluded that there was no 277 oxidation caused by the swirl flash drying treatment. Microalgal lipid components, especially PUFAs, 278 have shown swift response to several parameters like temperature, $\mathrm{pH}$, light and nutrient depletion 279 (Borges et al. 2011; Gao et al. 2013). Guldhe et al. (2014) compared different drying methods and their 280 effect on the fatty acid composition in microalgae. His study showed significant differences in 281 percentage of saturated and unsaturated fatty acids among all applied methods. He reported that oven 282 dried and freeze dried biomass had higher percentage of saturated fatty acid than sun dried biomass 283 while, surprisingly, freeze drying showed lowest percentage of PUFAs compared to the other two 284 methods. Spray drying, as an efficient drying method commonly used for microalgae drying, can 285 rupture the algal cells due to high-pressure in the atomizer nozzles, which means that quality of 286 pigments can be destroyed. Ryckebosch et al. (2011) found that freeze dried microalgae were more 287 susceptible to lipolysis than spray-dried microalgae, thus spray dried microalgae were more sensitive to 288 pigment oxidation than freeze dried microalgae, possibly due to breakdown of protecting carotenoids 
289 upon spray drying. Leach et al. (1998) reported that spray drying affected $\beta$-carotenoid recoveries from

290 D. salina, varying between $57 \%$ and $91 \%$, depending on the drying temperature.

291 Pigments

292 Both freeze and flash drying had an adverse effect on pigment composition of C. pyrenoidosa (Fig. 3).

293 These deviations between species can be attributed to the morphological differences of the microalgal 294 cell wall. Chlorella average cell size is 5-9 $\mu \mathrm{m}$, compared to the $N$. salina, 2-4 $\mu \mathrm{m}$ so the degree of 295 rupture may be also higher. It is important to point out that the Nannochloropsis sp. has thick cell wall 296 that is relatively hard to break down (Beacham et al. 2014). Due to this morphological characteristic, 297 bioactive compounds, such as PUFAs and pigments, are being additionally protected from unwanted 298 degradation during stress condition such as harvesting and drying.

299 Interestingly, drying processes significantly affected pigment composition (mainly chlorophylls) of $C$. 300 pyrenoidosa (Fig. 3), but the fatty acids profile showed no adverse effect. For the swirl flash drying 301 technique these results could be justified by the fact that the heat treatment of microalgae biomass 302 inactivates enzymes such as lipase and lipoxygenase, which can degrade the cellular lipids. For the 303 freeze dried biomass, presence of various natural antioxidants in the microalgae, including tocopherols 304 and carotenoids, which mostly remain intact during the freeze drying, might inhibit lipid oxidation, 305 which results in the PUFAs preservation. Furthermore, it should be noted that C. pyrenoidosa in 306 general contained very high concentrations of pigments and low concentrations of long chain PUFAs. 307 Deviations in the pigment composition of $C$. pyrenoidosa under tested treatments may be affected by 308 several factors. High temperatures during drying process may rupture the cell wall to some extent so 309 the extractability might be enhanced or it may destroy the pigments. However, that would not give an 310 explanation for freeze dried microalgae biomass. For freeze dried samples, ice crystallization, which 311 occurs during the freezing stage of the freeze drying, may have a crucial role. Even though freeze 312 drying is commonly used laboratory scale method and it is considered as a gentle drying technique for 313 microalgae, it should be noted that slow freezing rates between -20 to $-60^{\circ} \mathrm{C}$ will cause development of 314 large ice crystals in the intercellular spaces and result in the displacement of the constituent parts. If the 315 cells are rapidly frozen (e.g. in liquid nitrogen at $-196^{\circ} \mathrm{C}$ ), small intercellular ice crystals that would be 316 formed would not affect the cell morphology (Lin 1985). On the other hand, creating large ice crystals 317 may break the cell walls and in that way extractability of the pigments might be enhanced. That would 
explain significant difference in carotenoid concentration between freeze dried and non-dried 319 homogenized samples (3853 \pm 162 compared to $\left.2234 \pm 65 \mu \mathrm{g} \mathrm{g} \mathrm{g}^{-1} \mathrm{DW}\right)$.

\section{Tocopherols}

322 Tocopherols are natural antioxidant, known as free radical scavengers, which means they can inhibit or retard lipid oxidation. This suggests that tocopherols may be decomposed as a result of decreasing the instability of PUFA-s by scavenging oxidation induced radicals. Therefore, it is important to preserve these antioxidants also after the drying process for the stability of the microalgal biomass. As mentioned earlier, high temperature during drying may inactivate enzymes responsible for lipid oxidation. However, the enzymes remain intact in freeze-dried microalgae biomass, where antioxidants may have a crucial role in preventing unwanted lipid oxidation.

\section{Conclusion}

Drying technique for microalgae should be designed to eradicate possible deterioration of the sensitive bioactive compounds while being efficient and energy saving. A novel prototoype swirl flash dryer tested in this study was shown to be a promising drying technique for a microalgae biomass. Data showed no adverse effect on the fatty acid composition in microalgal biomass of drying by swirl flash dryer (for both $N$. salina and $C$. pyrenoidosa). That indicates that a high temperature and shear force applied during the drying process did not cause any degradation of fatty acids, which could be justified by the short drying time. High pressure homogenization and drying treatments caused degradation of chlorophylls and tocopherols in $C$. pyrenoidosa and, per contra, enhanced carotenoids extraction. The disruption of the microalgal cell wall seems to be the main factor that contributed to the degradation of these bioactive compounds by increasing their accessibility during the drying process.

Effect of the swirl flash drying method on the recovery of microalgal biomass and metabolites may differ between different specie depending on the cell morphology and biochemical composition. Therefore, more studies are needed on several different microalgal species, including testing of different drying parameters by swirl flash drying method. 
347 Funding: This research did not receive any specific grant from funding agencies in the public, 348 commercial, or not-for-profit sectors.

349 Conflict of interest: On behalf of all authors, the corresponding author states that there is no conflict of 350 interest.

\section{References}

Beachem TA, Bradley C, White DA, Bond P, Ali ST (2014) Lipid productivity and cell wall ultrastructure of six strains of Nannochloropsis: Implications for biofuel production and downstream processing. Algal Res 6:64-69.

Bligh EG, Dyer WJ, (1959) A rapid method of total lipid extraction and purification. Can J Biochem Physiol 37:911-917.

Borges L, Morón-Villarreyes JA, D’Oca MGM, Abreu PC, (2011) Effects of flocculants on lipid extraction and fatty acid composition of the microalgae Nannochloropsis oculata and Thalassiosira weissflogii. Biomass Bioenergy 35:4449-54.

Carballo-Cardenas EC, Tuan PM, Janssen M, Wijffels RH (2003) Vitamin E (alpha tocopherol) production by the marine microalgae Dunaliella tertiolecta and Tetraselmis suecica in batch cultivation. Biomol Eng 20:139-47.

Chisti Y, Moo-Young M (1986) Disruption of microbial cells for intracellular products. Enzyme Microb Technol 8:194-204.

Debrand S (1974) Heat transfer during a flash drying process. Ind Eng Chem Process Des 13:396404.

Firestone D, AOAC (2009) Official methods and recommended practices of the AOCS, 5th ed. American Oil Chemist's Society, Urbana, IL, USA.

Gao Y, Yang M, Wang C (2013) Nutrient deprivation enhances lipid content in marine microalgae. Bioresour Technol 147:484-91.

Grima EM, Belarbi EH, Acién Fernández FG, Medina AR, Chisti Y (2003) Recovery of microalgal biomass and metabolites: process options and economics. Biotechnol Adv 20:491-515.

Guldhe A, Singh B, Rawat I, Ramluckan K, Bux F (2014) Efficacy of drying and cell disruption techniques on lipid recovery from microalgae for biodiesel production. Fuel 128:46-52. 
Hosikian A, Lim Su, Halim R, Danquah MK (2010) Chlorophyll extraction from microalgae: A review on the process engineering aspects. Int J Chem Eng 2010:1-11, article ID 391632. Katie A (2000) APV Dryer Handbook. APV, Rosemount, Illinois. Lin LP (1985) Microstructure of spray-dried and freeze-dried microalgal powders. Food Structure 4(2), article 17. measurements of microalgal and cyanobacterial biomass. Bioresour Technol 101(19):7587-7591. Mendes-Pinto M, Raposo M, Bowen J (2001) Evaluation of different cell disruption processes on encysted cells of Haematococcus pluvialis: effects on astaxanthin recovery and implications for bio-availability. J App Phycol 13:19-24.

Orset S, Leach GC, Morais R, Young J (1999) Spray-drying of the microalga Dunaliella salina: effects on beta-carotene content and isomer composition. J Agric Food Chem 47:4782-4790.

Petrick I, Dombrowski L, Kröger M, Beckert T, Kuchling T, Kureti S (2013) DBFZ Report No. 16: Algae Biorefinery - Material and energy use of algae, 1-165.

Rossi N, Derouiniot-Chaplain M.P, Legentilhomme P, Petit I (2008) Arthrospira platensis harvesting with membranes: fouling phenomenon with limiting and critical flux. Bioresour Technol 99:6162-6167.

Ryckebosch E, Muylaert K, Eeckhout M, Ruyssen T, Foubert I (2011) Influence of drying and storage on lipid and carotenoid stability of the microalga Phaeodactylum tricornutum. J Agric Food Chem 59:11063-11069.

Ryckebosch E (2013) Microalgae as alternativesource of long chain omega-3 polyunsaturated fatty acids. PhD thesis, KU Leuven, Faculty of Bioscience Engineering, Kortrijk, Belgium.

Safafar H, Hass MZ, Møller P, Holdt SL, Jacobsen C (2016) High-EPA biomass from Nannochloropsis salina cultivated in a flat-panel photo-bioreactor on a process water enriched growth medium. Mar Drugs 14:144.

Safafar H, Jacobsen C, Reesbøll CA, Møller P (2017) An algae drier and a system for drying algae paste and/or liquid algae biomass, PCT/DK2017/050403.

Safafar H, van Wagenen J, Møller P, Jacobsen C (2015) Carotenoids, phenolic compounds and tocopherols contribute to the antioxidative properties of some microalgae species grown on industrial wastewater. Mar Drugs 13:7339-7356. 
Shelef G, Sukenik A, Green M (1984) Microalgae harvesting and processing: a literature review. doi:10.2172/6204677

Show KY, Lee DJ, Chang JS (2013) Algal biomass dehydration. Bioresour Technol 135:720-729.

Show KY, Lee DJ, Tay J, Lee T, Chang JS (2015) Microalgal drying and cell disruption - Recent advances. Bioresour Technol 258-266.

Spiden EM, Yap BHJ, Hill DRA, Kentish SE, Scales PJ, Martin GJO (2013) Quantitative evaluation of the ease of rupture of industrially promising microalgae by high pressure homogenization. Bioresour Technol 140:165-171.

Stramarkou M, Papadaki S, Kyeiakopoulou K, Krokida M (2017) Effect of drying and extraction conditions on the recovery of bioactive compunds from Chlorella vulgaris. J Appl Phycol 29:29472960.

Taher H, Al-Zuhair S, Al-Marzouqi AH, Haik Y, Farid M (2014) Effective extraction of microalgae

421

422

423

424

425

426

427

428

429

430

431

432

433

434 


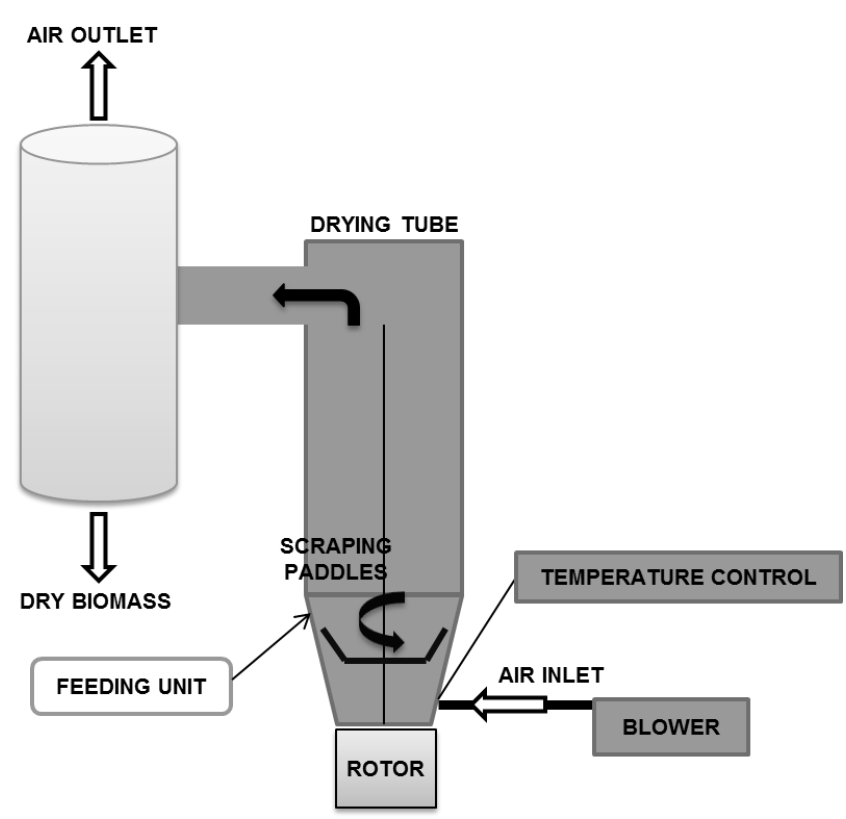

437 Figure 1. Schematic of prototype swirl flash dryer. Microalgae paste was introduced to the drying tube 438 by a peristaltic pump. At the conically shaped bottom of the drying tube there is an air inlet, through 439 which the hot air stream flows spirally into the drying chamber. Rotating scraping paddles with specific 440 aerodynamic design prevent the feed from adhering to the walls and disperse the feed to smaller 441 particles by providing the fluidizing spiral flow while moving the dried microalgal biomass to the 442 outlet.

444 Table 1. Drying conditions and specifications for prototype novel swirl dryer system.

\begin{tabular}{lll}
\hline Parameters & Range & Unit \\
\hline Feed rate & $1-5$ & $\mathrm{~kg} \mathrm{~h}^{-1}$ \\
Feed relative moisture content & $60-88$ & $\%$ \\
Feed viscosity & $20-50$ & $\mathrm{~Pa} \mathrm{~s}$ \\
Product moisture content & 8 & $\%$ \\
Product particle size range & $200-1500$ & $\mathrm{~nm}$ \\
\hline
\end{tabular}




\begin{tabular}{lll}
\hline Drying air temperature & $100-120$ & ${ }^{\circ} \mathrm{C}$ \\
Humidity of inlet air & 0.003 & $\mathrm{~kg} \mathrm{~kg}^{-1}$ air \\
Air density & 0.7 & $\mathrm{~kg} \mathrm{~m}^{-3}$ \\
Volumetric air flow rate & $18(\max 120)$ & $\mathrm{m}^{3} \mathrm{~h}^{-1}$ \\
Evaporation capacity & $\max 3.5$ & $\mathrm{~kg} \mathrm{~h}^{-1}$ \\
Drying tube length & 100 & $\mathrm{~cm}$ \\
Drying tube diameter & 12 & $\mathrm{~cm}$ \\
Scraping paddle speed & $\max 1000$ & $\mathrm{rpm}$ \\
\hline
\end{tabular}

445

446

447

448

449

450

451

452

453

454

455

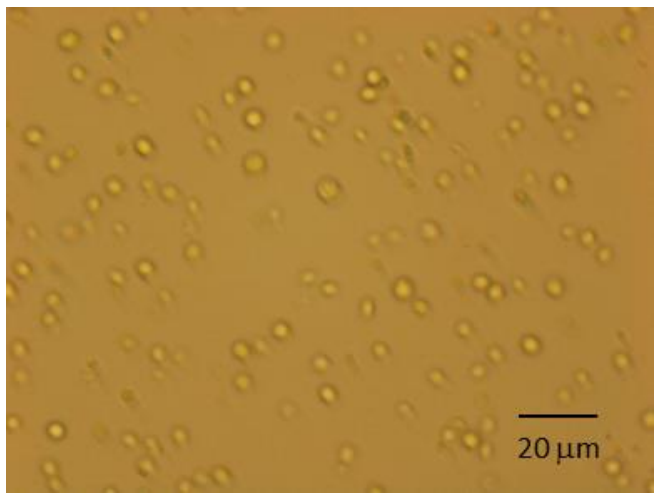

(a)

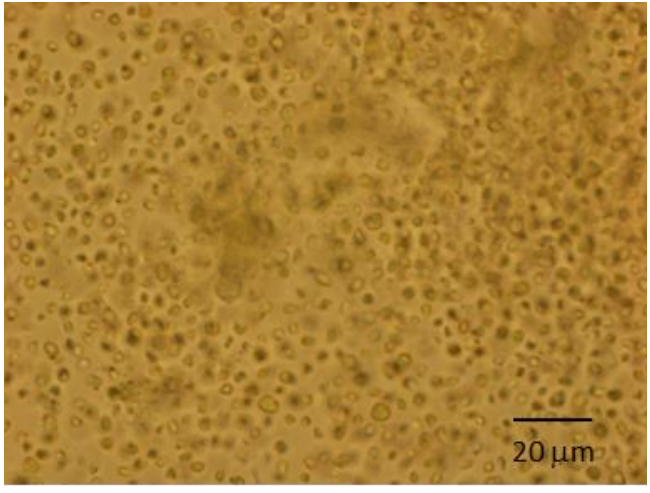

(b)

Picture 1. Chlorella pyrenoidosa (400x); (a) non-homogenized biomass, no cell rupture observed (b) homogenized biomass, moderate cell rupture observed. 
456 Table 2. Effect of drying and high-pressure homogenization on lipid and protein yield (\%) from $C$. 457 pyrenoidosa biomass. The results are presented as the means of $\mathrm{n}=2$ measurements from two 458 replicates \pm standard deviation. Different letters in the same column represent significant differences $(p$ $459<0.01)$.

\begin{tabular}{lrlll}
\hline & \multicolumn{2}{c}{ Total lipid (\%) } & \multicolumn{2}{c}{ Protein (\%) } \\
\hline Flash dried, homogenized & $12.12 \pm 1.05^{\mathrm{a}}$ & 38.49 & $\pm 1.51^{\mathrm{a}}$ \\
Flash dried, non-homogenized & 11.02 & $\pm 0.15^{\mathrm{a}}$ & 37.59 & $\pm 0.70^{\mathrm{a}}$ \\
Freeze dried, homogenized & 12.25 & $\pm 0.46^{\mathbf{a}}$ & $39.51 \pm 0.15^{\mathbf{a}}$ \\
Freeze dried, non-homogenized & $11.38 \pm 0.17^{\mathrm{a}}$ & $39.98 \pm 1.28^{\mathbf{a}}$ \\
Non-dried, homogenized & $12.29 \pm 0.01^{\mathrm{a}}$ & $39.07 \pm 2.27^{\mathbf{a}}$ \\
Non-dried, non-homogenized & $9.04 \pm 0.02^{\mathbf{b}}$ & $38.98 \pm 0.61^{\mathbf{a}}$ \\
\hline
\end{tabular}

460

461

462 Table 3. Fatty acid composition (\% of total FA) of swirl flash-dried and non-dried N. salina. The 463 results are presented as the means of $n=2$ measurements from two replicates \pm standard deviation. 464 Different letters in the same row represent significant differences $(p<0.01)$.

\begin{tabular}{|c|c|c|c|}
\hline Fatty acid & \multicolumn{2}{|c|}{ Non-dried } & Swirl flash dried \\
\hline 14:00 & 2.84 & $\pm 0.42^{\mathrm{a}}$ & $3.62 \pm 0.32^{\mathrm{a}}$ \\
\hline 15:00 & 0.37 & $\pm 0.02^{\mathrm{a}}$ & $0.43 \pm 0.00^{\mathrm{a}}$ \\
\hline 16:00 & 24.00 & $\pm 0.75^{\mathrm{a}}$ & $21.14 \pm 1.09^{\mathrm{a}}$ \\
\hline 16:1 (n-7) & 31.23 & $\pm 0.93^{\mathrm{a}}$ & $\pm 1.87^{\mathrm{a}}$ \\
\hline $16: 2(n-4)$ & 1.59 & $\pm 0.07^{\mathrm{a}}$ & $1.57 \pm 0.10^{\mathrm{a}}$ \\
\hline $16: 3(n-4)$ & 0.51 & $\pm 0.06^{\mathrm{a}}$ & $0.30 \pm 0.06^{\mathrm{a}}$ \\
\hline $16: 4(n-1)$ & 0.00 & $\pm 0.03^{\mathrm{a}}$ & $0.48 \pm 0.08^{b}$ \\
\hline 18:00 & 0.91 & $\pm 0.01^{\mathrm{a}}$ & $0.63 \pm 0.03^{b}$ \\
\hline 18:1 (n-9) & 4.58 & $\pm 0.25^{\mathrm{a}}$ & $4.14 \pm 0.11^{\mathrm{a}}$ \\
\hline 18:1 (n-7) & 1.64 & $\pm 0.02^{\mathrm{a}}$ & $0.78 \pm 0.03^{b}$ \\
\hline $18: 2(n-6)$ & 2.18 & $\pm 0.05^{\mathrm{a}}$ & $2.13 \pm 0.01^{\mathrm{a}}$ \\
\hline $18: 3(n-3)$ & 0.90 & $\pm 0.12^{\mathrm{a}}$ & $0.00 \pm 0.23^{\mathbf{b}}$ \\
\hline 20:1 (n-9) & 0.34 & $\pm 0.10^{\mathrm{a}}$ & $\pm 0.02^{b}$ \\
\hline
\end{tabular}




\begin{tabular}{lrllll}
\hline $\mathbf{2 0 : 4}(\mathbf{n}-6)$ & 1.71 & \pm & $0.06^{\mathrm{a}}$ & 2.00 & $\pm 0.05^{\mathrm{b}}$ \\
$\mathbf{2 0 : 3}(\mathbf{n - 3})$ & 0.26 & $\pm 0.02^{\mathrm{a}}$ & 0.00 & $\pm 0.02^{\mathrm{b}}$ \\
$\mathbf{2 0 : 5}(\mathbf{n - 3})$ & 25.92 & $\pm 0.69^{\mathrm{a}}$ & 25.63 & $\pm 1.17^{\mathrm{a}}$ \\
$\mathbf{2 2 : 5}(\mathbf{n}-3)$ & 0.48 & $\pm 0.05^{\mathrm{a}}$ & 0.16 & $\pm 0.03^{\mathrm{b}}$ \\
$\mathbf{2 2 : 6}(\mathbf{n - 3})$ & 0.23 & $\pm 0.01^{\mathrm{a}}$ & 0.12 & $\pm 0.10^{\mathrm{a}}$ \\
\hline $\boldsymbol{\Sigma}$ SAFA & 28.12 & $\pm 1.20^{\mathrm{a}}$ & 25.82 & $\pm 1.44^{\mathrm{a}}$ \\
$\boldsymbol{\Sigma}$ MUFA & 37.79 & $\pm 1.30^{\mathrm{a}}$ & 40.62 & $\pm 2.03^{\mathrm{a}}$ \\
$\boldsymbol{\Sigma}$ PUFA & 33.77 & $\pm 1.16^{\mathrm{a}}$ & 32.40 & $\pm 1.85^{\mathrm{a}}$
\end{tabular}

465 SAFA, saturated fatty acids; MUFA, monounsaturated fatty acids; PUFA, polyunsaturated fatty acids 466

467

468 
Table 4. Fatty acid content (\% of total FA) in the biomass of $C$. pyrenoidosa after applying different drying techniques with and without pre-treatment by high-pressure homogenization. The results are presented as the means of $n=2$ measurements from two replicates \pm standard deviation. Different letters in the same row represent significant differences $(p<0.01)$.

\begin{tabular}{|c|c|c|c|c|c|c|c|c|c|c|c|c|c|}
\hline \multirow{2}{*}{$\begin{array}{l}\text { Fatty acid } \\
14: 0\end{array}$} & \multicolumn{2}{|c|}{$\begin{array}{l}\text { Flash dried, } \\
\text { homogenized }\end{array}$} & \multicolumn{2}{|c|}{$\begin{array}{c}\text { Flash dried, non } \\
\text { homogenized }\end{array}$} & \multicolumn{3}{|c|}{$\begin{array}{l}\text { Freeze dried, } \\
\text { homogenized }\end{array}$} & \multicolumn{2}{|c|}{$\begin{array}{c}\text { Freeze dried,non } \\
\text { homogenized }\end{array}$} & \multicolumn{2}{|c|}{$\begin{array}{c}\text { Non-dried, } \\
\text { homogenized }\end{array}$} & \multicolumn{2}{|c|}{$\begin{array}{c}\text { Non-dried, non } \\
\text { homogenized }\end{array}$} \\
\hline & 0.28 & $\pm 0.06^{\mathrm{a}}$ & 1.57 & $\pm 0.07^{\mathbf{b}}$ & 1.75 & + & $0.06^{b}$ & 0.30 & $\pm 0.09^{\mathrm{a}}$ & 0.58 & $\pm 0.38^{\mathrm{a}}$ & 1.35 & $0.01^{b}$ \\
\hline 15:0 & 0.11 & $\pm 0.01^{\mathrm{a}}$ & 0.39 & $\pm 0.01^{b}$ & 0.36 & \pm & $0.01^{\mathrm{b}}$ & 0.09 & $0.01^{\mathrm{a}}$ & 0.10 & $0.00^{\mathrm{a}}$ & 0.27 & $0.01^{\mathbf{b}}$ \\
\hline 16:0 & 20.74 & $\pm 0.36^{\mathbf{a b}}$ & 19.87 & $0.02^{b}$ & 20.08 & \pm & $0.05^{\mathbf{b}}$ & 20.85 & $0.37^{\mathbf{b}}$ & 21.70 & $0.07^{\mathrm{ac}}$ & 19.63 & $0.17^{\mathbf{b}}$ \\
\hline $16: 1(n-7)$ & 2.26 & $\pm 0.16^{\mathrm{a}}$ & 2.45 & $\pm 0.01^{\mathrm{a}}$ & 2.44 & \pm & $0.00^{\mathrm{a}}$ & 2.28 & $0.17^{\mathrm{a}}$ & 2.39 & $0.02^{\mathrm{a}}$ & 2.47 & $0.03^{\mathrm{a}}$ \\
\hline $16: 2(n-4)$ & 8.39 & $\pm 0.22^{\mathrm{a}}$ & 8.62 & $0.45^{\mathrm{a}}$ & 8.78 & \pm & $0.01^{\mathrm{a}}$ & 8.46 & $0.20^{\mathrm{a}}$ & 8.47 & $0.06^{\mathrm{a}}$ & 8.90 & $0.03^{\mathrm{a}}$ \\
\hline $16: 3(n-4)$ & 12.37 & $\pm 0.34^{\mathrm{a}}$ & 13.20 & $\pm 0.17^{\mathrm{a}}$ & 12.95 & \pm & $0.04^{\mathrm{a}}$ & 12.46 & $0.30^{\mathrm{a}}$ & 12.33 & $0.20^{\mathrm{a}}$ & 13.14 & $0.05^{\mathrm{a}}$ \\
\hline 18:0 & 0.86 & $\pm 0.24^{\mathrm{a}}$ & 0.57 & $\pm 0.01^{\mathrm{a}}$ & 0.64 & \pm & $0.05^{\mathrm{a}}$ & 0.86 & $0.25^{\mathrm{a}}$ & 0.66 & $0.02^{\mathrm{a}}$ & 0.59 & $0.00^{\mathrm{a}}$ \\
\hline $18: 1(n-7)$ & 6.38 & $\pm 0.72^{\mathrm{a}}$ & 5.66 & $\pm 0.48^{\mathrm{a}}$ & 5.71 & \pm & $0.05^{\mathrm{a}}$ & 6.43 & $0.74^{\mathrm{a}}$ & 5.76 & $0.02^{\mathrm{a}}$ & 5.63 & $0.16^{\mathrm{a}}$ \\
\hline $18: 2(n-6)$ & 21.29 & $\pm 0.09^{\mathbf{a b}}$ & 20.83 & $\pm \quad 0.10^{\mathrm{a}}$ & 20.72 & \pm & $0.08^{\mathrm{a}}$ & 21.45 & $0.02^{\mathbf{b}}$ & 21.33 & $0.04^{\mathrm{ab}}$ & 20.94 & $0.03^{\mathrm{ab}}$ \\
\hline $18: 3(n-3)$ & 26.65 & $\pm 0.58^{\mathrm{a}}$ & 26.84 & $\pm 0.06^{\mathrm{a}}$ & 26.58 & \pm & $0.04^{\mathrm{a}}$ & 26.78 & $\pm 0.42^{\mathrm{a}}$ & 26.68 & $0.18^{\mathrm{a}}$ & 27.08 & $0.01^{\mathrm{a}}$ \\
\hline$\Sigma$ SAFA & 21.98 & $\pm 0.67^{\mathrm{a}}$ & 22.40 & $0.10^{\mathrm{a}}$ & 22.83 & \pm & $0.17^{\mathrm{a}}$ & 22.11 & $\pm \quad 0.72^{\mathrm{a}}$ & 23.04 & $0.48^{\mathrm{a}}$ & 21.84 & $0.19^{\mathrm{a}}$ \\
\hline$\Sigma$ MUFA & 8.63 & $\pm 0.87^{\mathrm{a}}$ & 8.11 & $0.49^{\mathrm{a}}$ & 8.14 & \pm & $0.05^{\mathrm{a}}$ & 8.70 & $\pm 0.91^{\mathrm{a}}$ & 8.15 & $0.05^{\mathrm{a}}$ & 8.11 & $0.20^{\mathrm{a}}$ \\
\hline$\Sigma$ PUFA & 68.70 & $\pm 1.24^{\mathrm{a}}$ & 69.49 & $\pm 0.78^{\mathrm{a}}$ & 69.03 & \pm & $0.16^{\mathrm{a}}$ & 69.16 & $\pm 0.93^{\mathrm{a}}$ & 68.80 & $\pm 0.48^{\mathrm{a}}$ & 70.06 & $\pm 0.12^{\mathrm{a}}$ \\
\hline
\end{tabular}


473

474

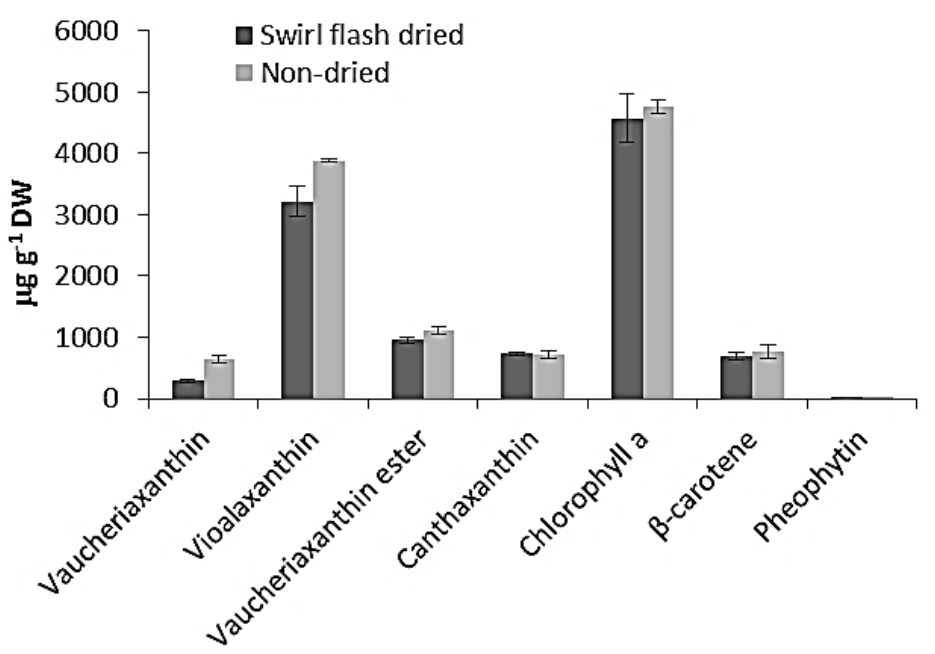

475 Figure 2. Pigment composition ( $\mu \mathrm{g} \mathrm{g}^{-1}$ dry biomass) of swirl flash-dried and non-dried N. salina. The 476 results are presented as the means of $n=2$ measurements from two replicates; error bars represent 477 standard deviation.

478

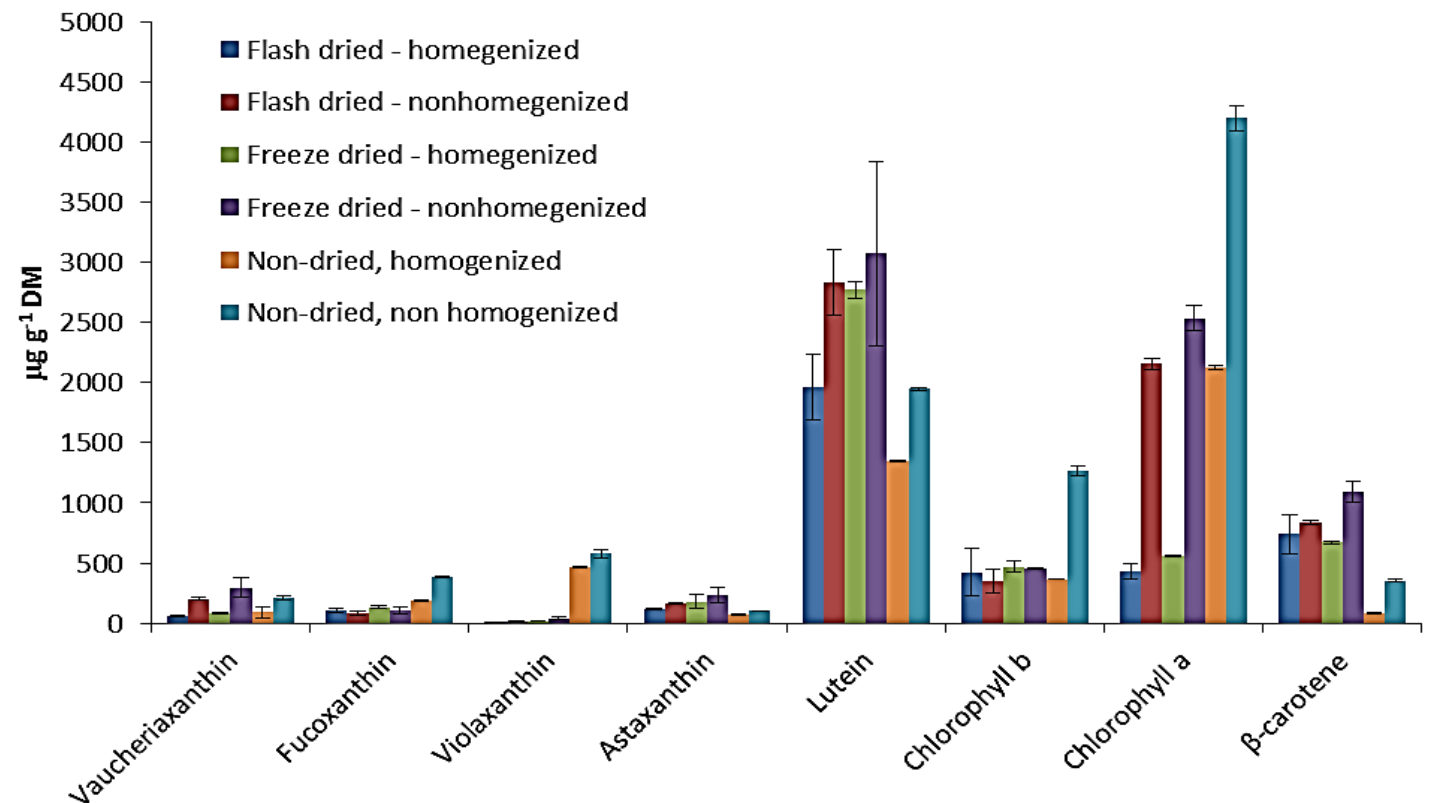

480 Figure 3. Pigment composition ( $\mu \mathrm{g} \mathrm{g}^{-1}$ dry biomass) of $C$. pyrenoidosa after applying two different 481 drying techniques with and without pre-treatment by high-pressure homogenization. The results are 
482 presented as the means of $\mathrm{n}=2$ measurements from two replicates; error bars represent standard 483 deviation.

484 Table 5. Content of carotenoids and chlorophylls ( $\mu \mathrm{g} \mathrm{g}^{-1}$ dry biomass) in C. pyrenoidosa after applying 485 two different drying techniques with and without pre-treatment by high-pressure homogenization. The 486 results are presented as the means of $n=2$ measurements from two replicates \pm standard deviation.

487 Different letters in the same column represent significant differences $(p<0.01)$.

\begin{tabular}{lllllll}
\hline \multicolumn{1}{c}{ Microalgal biomass } & \multicolumn{2}{c}{ Carotenoids } & \multicolumn{2}{c}{ Chlorophylls } & \multicolumn{2}{c}{ Total pigments } \\
\hline Flash dried, homogenized & $3001 \pm 469^{\mathbf{a b}}$ & $852 \pm 260^{\mathbf{a}}$ & $3854 \pm 729^{\mathbf{a}}$ \\
Flash dried, non-homogenized & $4127 \pm 320^{\mathbf{b}}$ & $2504 \pm 142^{\mathbf{b}}$ & $6631 \pm 463^{\mathbf{b}}$ \\
Freeze dried, homogenized & $3853 \pm 162^{\mathbf{b}}$ & $1032 \pm 46^{\mathbf{a}}$ & $4885 \pm 209^{\mathbf{a}}$ \\
Freeze dried, non-homogenized & $4836 \pm 1093^{\mathbf{b}}$ & $2990 \pm 104^{\mathbf{b}}$ & $7826 \pm 1197^{\mathbf{b c}}$ \\
Non-dried, homogenized & $2234 \pm 65^{\mathbf{a}}$ & $2490 \pm 16^{\mathbf{b}}$ & $4725 \pm 81^{\mathbf{a}}$ \\
Non-dried, non-homogenized & $3576 \pm 84^{\mathbf{b}}$ & $5458 \pm 141^{\mathbf{c}}$ & $9034 \pm 225^{\mathbf{c}}$ \\
\hline
\end{tabular}

488

489

490

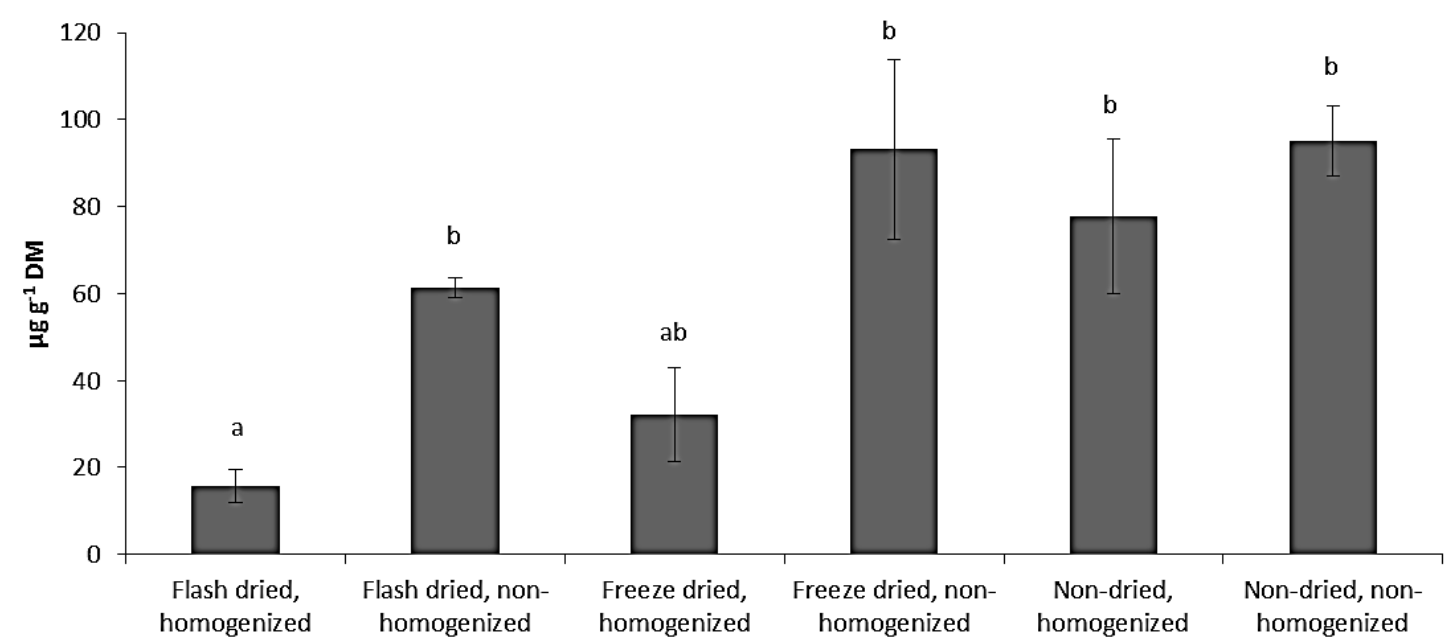

491 Figure 4. Tocopherol content ( $\mu \mathrm{g} \mathrm{g}^{-1}$ dry biomass) in C. pyrenoidosa after applying different drying 492 techniques with and without pre-treatment by high-pressure homogenization. The results are presented 493 as the means of $\mathrm{n}=2$ measurements from two replicates; error bars represent standard deviation. 494 Different letters represent significant differences $(p<0.01)$. 